\title{
Virus-induced gene silencing for functional analysis of selected genes
}

Mandar R. Godge · Arunima Purkayastha ·

Indranil Dasgupta $\cdot$ Prakash P. Kumar

Published online: 16 December 2008

(C) Springer-Verlag 2008

Erratum to: Plant Cell Rep (2008) 27:209-219

DOI 10.1007/s00299-007-0460-2

This article has been withdrawn due to copyright violation.

The online version of the original article can be found under doi:10.1007/s00299-007-0460-2.

M. R. Godge · P. P. Kumar $(\bowtie)$

Department of Biological Sciences, Faculty of Science,

National University of Singapore,

Singapore 117543, Singapore

e-mail: dbskumar@nus.edu.sg

A. Purkayastha $\cdot$ I. Dasgupta $(凹)$

Department of Plant Molecular Biology,

University of Delhi South Campus,

New Delhi 110021, India

e-mail: indranil58@yahoo.co.in 